\title{
Stanislavski, Shpet, and the Art of Lived Experience
}

\section{Frederick Matern}

In the first issue of Stanislavski Studies, John Gillett (2012) asked whether we were getting closer to the core of Stanislavski's approach. The purpose of the present paper is to suggest that we probably are getting closer, thanks in great measure to the work of the scholars and practitioners of acting who have contributed to the early issues of this journal, but that the answer to the question is a problem not only of translation, but one of philosophical discovery, for hidden in Stanislavski's practical approach is the philosophical question of "what is theatre as an art", and "how does the actor fit into that art". It is interesting and perhaps telling that in America and throughout the English-speaking world, Stanislavski's system, without his sanction, was propagated as "the Method", for indeed it seems that one of the difficulties was that a part of Stanislavski's methodology was exported, leaving behind the underlying aesthetic assumptions that informed Stanislavski's art. This is not to downplay the achievements of the method acting schools in America. Rather, before holding up any version or iteration of Stanislavski's System as being more authentic, more work has to be done to understand the purpose for which he developed his approach. It is as if, in the English-speaking world, we have been given a map showing roads, but none of the physical features underneath: no mountains, coasts or rivers.

Stanislavski, by his own admission, was not a professional philosopher, but he clearly developed a philosophy as regards the aesthetics of the theatre. Later in his life, after he had formulated his System, there is one philosopher with whom he collaborated: Gustav Gustavovich Shpet, who was a student of Edmund Husserl and continued to develop hermeneutics, the science of interpretation. Shpet is regarded as an important figure in $20^{\text {th }}$
Century Russian philosophy. It is very interesting that he was given the task of coming up with a curriculum for a theatre school under the management of Moscow Art Theatre during the 1920 s. It is my view that a great deal remains to be discovered about the relationship and exchange of ideas between the great director and the philosopher. A look at Shpet's philosophy of the theatre might therefore bear fruit in revealing more about the underlying aesthetic assumptions of Stanislavski's system, particularly during its later stages.

Sharon Marie Carnicke has recently argued (2009) that Stanislavski's central concept - the "lost term" of perezhivanie, or, as she, Jean Benedetti, and other scholars translate it, "experiencing"-led Stanislavski into a fundamental contradiction: in the great debate on acting that Diderot called "the paradox of acting" he, unlike Diderot, took the side of the 'sensible' actor, promoting a theatre where the actor is taught by various means to experience the role. When it actually comes to performing roles on stage, however, Carnicke maintains that Stanislavski's "eccentric and ambiguous" use of "experiencing" in acting was in reality quite messy (2009:141). She then goes further and says that Stanislavski not only appropriates Diderot, but that Diderot's model reflects Stanislavski's own experience on stage (142). Here I argue that Diderot's theory is, rather, incommensurable not only with Stanislavski's teaching but also his practice and that of later generations of Russian artists. My view is that Carnicke's reading of the Russian word translated as "experiencing" (perezhivanie) relies too heavily on Tolstoy's theory of art which, indeed, exerted an influence on Stanislavski but not necessarily, to such an extent, on his use of the noun in question. 
The problem Carnicke is addressing has to do with Stanislavski's use of the concept of theatrical truth. She notes that Stanislavski takes up the idea as conceived by the Romantics. Indeed, one of the foundations of Stanislavski's aesthetics is based on an idea framed by Pushkin (as quoted in Jean Benedetti's translation of An Actor's Work): "Truth of the passions, feelings that seem true in the proposed circumstances, that is what our intellect requires of a dramatist", with the small correction from "proposed" to "given" circumstances, reflecting the fact that in the theatre, the playwright usually imposes circumstances on the actor (Stanislavski 2008: 52). Truth and sincerity are central to Stanislavski's teaching, but when confronted with the reality of theatrical performance, the actor cannot forget that he is playing a role. As Carnicke puts it, "actors face a tough practical choice. They must either align their feelings with those of a playwright, or superimpose their own texts onto the author's" (2009: 141). She concludes by finding that Stanislavski essentially finds a "postmodern" solution to this dichotomy, where "perezhivanie" becomes synonymous with "creating" (144). "When Stanislavski suggests evaluating performance on its own terms and seeing 'truth' as relative to the play, he travels away from Tolstoy and anticipates developments in modernism that embrace the formal media of art" (145).

Stanislavski's creation was a system and not simply a method. This fact has been emphasized time and again by Stanislavski scholars but it bears repeating: there are of course many methodological elements in his teachings, but they are meant to buttress a view of what theatre art should be. Without understanding that view, any work on Stanislavski's methodology risks being done in a vacuum. Also, despite the vast efforts that have been made to create methodologies for learning the art of acting in the Englishspeaking world that have been inspired by Stanislavski's system, it is interesting to note how acting, as it is very often done by professional artists in Russia, differs from the acting very often done by no less experienced professional artists in the English-speaking world. I would suggest that pedagogy focused on the methodological aspects of Stanislavski's system may miss the more fundamental aspects of the theatre he was trying to promote, which, I think, is easier for Russian students to understand, wrapped up as it is in that one word we are having trouble elucidating: perezhivanie.

Benedetti (1990) and Carnicke (2009) have described in detail the factors underlying the gulf between Stanislavski as he is known to Western world and Stanislavski as he is taught in Russia. This difference can be explained in part by translations into English by Robbins and Hapgood which are, in effect, very different manuscripts from those that were published in the USSR. As Burnet Hobgood (1973), Benedetti, and Carnicke point out, a key technical term in Stanislavski's system for actors went missing in the English language publications through which he became known to the West. The word "perezhivanie", the subtitle of Stanislavski's key text for actors (translated by Benedetti as An Actor's Work: A Student's Diary. Year One: Experiencing), was simply dropped from the title of the Hapgood translation (An Actor Prepares). In the case of J.J. Robbins' translation of My Life in Art, the word is rendered by "living... through" (p. 159), "living" (p. 160), "inner creation" (p. 210), "examining" (p. 459), "experiencing" (p. 460) and "living over" (p. 462). A similar variety of terms can be found in Hapgood's translation. As Carnicke pointed out in her essay on translating An Actor's Work (1984), the experiences of reading Stanislavski in English and Russian are very different. The loss of the word as a technical term led to confusion in actor education. Furthermore, the not-quite-accurate rendering of perezhivanie as "re-living" emotions led, in the end, to a controversial style of actor training that later provided critics of Stanislavski's system, such as David Mamet, something of a straw man to 
discredit. "Dead pet acting" can be decried as the stultifying legacy of academic theatre education but has little to do with what Stanislavski wrote or taught (Maxwell 2008). In the English-speaking world, it was only through the work of such scholars as Carnicke and, of course, Benedetti, that a serious attempt to revive the word as a technical term was accomplished. Now, it would seem that this concept is here to stay in the English literature on Stanislavski.

Experiencing is part of a triad of technical terms Stanislavski uses to describe three "trends" in theatre art. In an essay on these trends, translated by Benedetti (2007) ${ }^{1}$, Stanislavski describes them as Craft, the Art of Representation, and the Art of Experiencing. Benedetti, who makes it clear in the introduction to his book that the translations are his own and that he is aiming to achieve a clear understanding for his audience of theatre practitioners rather than scholastic accuracy, takes a liberty with the translation of the word for "craft" (remeslo): he renders it as "hackwork". For the purposes of this paper it is important to note that Stanislavski did not choose a Russian word corresponding to "hackwork" with its pejorative tone (i.e. khaltura), but used a word that is fairly unambiguously rendered as "craft" to describe the mechanical, cliché-ridden, "not artistic" (Benedetti 2007, 111) acting that he was struggling to overcome with his System. Benedetti, I suspect, would have felt that the term "craft" with some of its positive connotations might confuse the Englishspeaking reader. In his translation of $A n$ Actor's Work he substitutes "stock-in-trade", a term of somewhat more ambiguous value, less negative than "hackwork". But that ambiguity, or rather neutrality in terms of value, already exists in the Russian term that Stanislavski chose; he turns craft (remeslo) into something negative, since it is "not art". For him, it is embodied in the "actorish state" which is not the proper creative state (Stanislavski 2008, 299), but just as craft can be aesthetically pleasant in other contexts, here an audience can become used to theatrical conventions that they can "even love" (Stanislavski, quoted in Benedetti 2007, 115). But whether we adopt the term "stock-in-trade" or "craft" is not overly critical in terms of understanding the System and its aesthetic underpinnings. Once defined by Stanislavski, the concept is selfcontained and clear in either translation.

The trend he labels "the art of representation", the theory that finds its clearest expression in Diderot (1830/1957), is even easier to understand in translation. "Representation" is a straightforward translation of the Russian predstavlenie. With stock-in-trade (or, as I would prefer, simply "craft") and representation, we have a good beginning of a technical glossary for Stanislavski in English. There is, however, a problem with the third and central term, which is simply that the word "experience" or even "experiencing" does not entirely capture that which Russian theatre artists are talking about when they use the term perezhivanie. Much of the discussion from here on out will be centered around "experiencing": should an actor be doing this, and if so, what "experiences" should the actor be having? Already, by settling on "experience" or "experiencing" to translate the key term in Stanislavski, we are using a word with a less precise meaning than the one he chose.

It is not disputed that "experience" has been used to translate the word in different contexts. The question is whether that translation of the word captures, for the English-speaking audience, the meaning that we want. Looking at it from another angle, it can truly be said that the English noun "experience", when unqualified, is usually translated into Russian as "opyt". The verb "to experience" is likewise normally translated as "ispytyvat". A certain amount of qualification would normally be

\footnotetext{
${ }^{1}$ The essay is entitled, "Various trends in the art of the theatre", translated and abridged in Benedetti (2007), pp. 111-120. The Russian original can be found in Stanislavski (1994), pp 42-104.
} 
needed to translate the noun form of the word "experience" into Russian as "perezhivanie". Interestingly, Hobgood uses Dewey's elucidation of the word experience from the book Art as Experience to describe Stanislavski's term (1974, p. 150), but it is worth pointing out that the title of Dewey's book was translated in Russian philosophical literature as "Iskusstvo kak $\underline{O p y t}$ "

Furthermore, the objections Hobgood raises against at least some of the calques that were used to translate the term are not entirely satisfying. Hobgood writes that "the merest knowledge of the Russian tongue would demonstrate how much easier it would have been for him to say 'live the role,' but he did not do so and I think we are safe in concluding he did not mean that" (149). That is a strong assertion but it appears to depend on how Hobgood thought "live the role" could be rendered in Russian. "To live" is a transitive verb in this context, and connotes, not surprisingly, experiencing something (like a role) when used this way in English. The Russian verb zhit' is intransitive. "The role" in Russian simply cannot take the accusative of the verb zhit'. Interestingly, the verb perezhivat' is transitive. This is a point where English and Russian are not compatible. It is incorrect to assert, in English, that it would have been easier to use the phrase "live (zhit') the role" in Russian, since there is no way to say it this way with the intransitive verb. Looking at it this way, translating Stanislavski as teaching "living the part" might not be so far off the mark after all. It could be that the problem later encountered by the Method does not stem from an error induced by the idea of "living the part" itself, but from an interpretation of what living the part could actually mean.

As we look deeper into the meaning of the noun, perezhivanie, we find more evidence that it has a complex history. Hobgood takes the verb form, perezhivat', a very common verb that has deep roots in the Russian language, and from there generalizes the meaning of the noun. Even using the sources he cites for translating the verb, however, it is not clear that we can generalize the verb to mean "to experience" the way we normally mean it. The verb is, indeed, translated as "to experience" in Chapter V of Tolstoy's What is Art? (translated by Aylmer Maude), where Tolstoy talks about "experiencing feelings". But the story is more complex. In the same footnote, Hobgood refers us also to Chapter $\mathrm{XV}$ of Tolstoy's essay, but in that chapter, what appears in translation as the verb "to experience (a feeling, a mental state)" is expressed exclusively by the verb ispytyvat' in the original. Perhaps more significantly, the noun form of the word, "perezhivanie", does not appear in that essay at all. In fact, the noun was evidently a latecomer to the Russian language. Not only did Tolstoy not use it in What is Art? the noun does not appear as late as the second edition (1880) of Dal's Explanatory Dictionary of the Living Great Russian Language. The verb form, perezhivat', at the time Tolstoy wrote his essay, was defined in Dal's Dictionary in this specific context as "to experience, to see, to endure much in one's age".

None of the foregoing means that one can't translate perezhivanie as "experience" or "experiencing" in the right context, but the fact that the noun is a latecomer to the Russian language is significant for our study of Stanislavski, and the aesthetic assumptions underlying his introduction to the Englishspeaking world: "living the part", after all, is a calque of this noun. It turns out that there is a good case to be made that the Russian noun is itself a recent calque of a German word used extensively in philosophy, Erlebnis. It is also the case that this German noun form of the verb erleben (which, like the Russian verb, had been common before the $19^{\text {th }}$ Century) was a latecomer to the German language. Hans-Georg Gadamer explains some of this history in Truth and Method. Erlebnis as a

\footnotetext{
${ }^{2}$ see, for example, Stolovich $(1994,186)$.
} 
noun was first popularized in the late $19^{\text {th }}$ Century by the philosopher known as the founder of the Human Sciences, Wilhelm Dilthey (Gadamer 2004, 56). Behind the coining of that noun was a history of German speculative idealism (Fichte, Hegel) and the influence of Rousseau (55). Gadamer implies, given this history, that the word in German carries a "back-to-nature" ring. This would lend credence to the idea that the root element of "life" in the word is significant. The same would almost certainly apply to the Russian word perezhivanie. The word Erlebnis took on a specialized meaning in Dilthey's hermeneutics and in Husserl's phenomenology. In Husserl it is normally translated as something "lived", or "vécu" in French (Cairns 1973, 46). In translations of Dilthey (1985) "lived experience" is used. I would propose that this would also be a more exact way to translate Stanislavski's perezhivanie as a technical term of aesthetics.

Considering this apparent terminological link to hermeneutics, it is worth noting that Stanislavski collaborated with a student of Husserl's: Gustav Shpet, who was a leading philosopher in Russia in the hermeneutic tradition at the beginning of the $20^{\text {th }}$ Century. Stanislavski makes only a few references to their collaboration in his letters, but it is important to remember that Shpet's legacy was nearly obliterated together with the man. He wrote influential monographs on the subject of hermeneutics and is also the author of the definitive translation in Russian of Hegel's Phenomenology of the Spirit (completed in exile in Siberia, shortly before he was murdered in 1937, and not credited to him until he was rehabilitated many years later: see Tihanov 2009). It is a known fact that he collaborated closely with the Moscow Art Theatre in the 1920's, even to the point of drafting a curriculum for a proposed theatre college (Aristov 2009). He appears fleetingly at several points in Stanislavski's collected letters (for example, Stanislavski 1999, 452). As a leading Russian scholar of hermeneutics and a student of Husserl, however, he had a very clear insight into the concept of Erlebnis. It just so happens that the philosophical grounding of the theatre as an art form was one of his most important preoccupations.

In his 1921 essay on "Theatre as Art", Shpet argued that the material of the art of the theatre is the actor himself. The actor creates out of himself but is not "playing himself" (Shpet 1989, 73); nor does he embody a literary work since the text before the actor is not literature, but a "role", a bare text containing a potentiality of actual performances (75). Really, the playwright's text is more analogous to the conventions around stock characters in Commedia del'Arte (78). The text of a play, for an actor, is there, strictly speaking, to give the actor "a 'sprit', an idea, a tendency, a task" (75). On the other hand, while the actor's material, his canvas, is the actor himself along with his ability to express himself; his expressiveness is not "the person he is in real, normal everyday life," but "an artistic portrayal of a given idea in some aesthetically conventional form" (81). Shpet's view offers a third way out of the stark choice as Carnicke framed it.

He also points out that certain mistakes had been made (for example, in the early work of the Moscow Art Theatre) which stemmed from a misunderstanding of the concept of perezhivanie. "Experience" [perezhivanie], Shpet writes, "was construed as the very content of the actor's creativity. Insofar as aesthetics adopted this theory it fell into a psychologistic error, while at the same time ignoring the laws of psychology" (85). The mistake is "the assumption that it is necessary to evoke in oneself a certain experience in order for the needed expression to emerge of itself" (86). This analysis is Shpet's critique of the use of sense-memory and anticipates much recent criticism of Method Acting, and it shows that the word perezhivanie could be just as prone to misinterpretation as the idea of "living the part" that I raised earlier.

Carnicke notes the passage in An Actor's Work where Tortsov is subjected to a fake operation, 
and his alternating sense of reality and fiction. "Diderot's philosophy", she concludes, "need not turn the actor into an inauthentic personality after all... Stanislavsky reinterprets Diderot's model, transforming the active/ passive dichotomy... into one of belief/ disbelief" (2009, 144). But here, it seems, is where the difference in interpreting what experiencing (perezhivanie) means in the context of a stage performance. For Stanislavski, the goal of experiencing was less, in my view, to radiate emotions (the Tolstoyan explanation favoured by Hobgood and Carnicke) and more about tapping into the creativity of life as expressed through the unconscious, effectively creating a new work of art with each performance. Diderot's art of representation, however, does the opposite. It is designed precisely to stamp out the same work of art, night after night (although it does qualify, for Stanislavski, as art, as opposed to craft). It valorizes the rational, aesthetic mind over the somatic body. For Carnicke, the place where Stanislavski appears to agree with Diderot is when theory ends and the actual, real-life work of performing on stage begins, and he adopts Diderot by way of interpretation. This would appear to be based on a reading that the key to Diderot's model is a split consciousness, while Stanislavski insists on unity of consciousness in his theoretical writing but refers to a division of the self in his more practical writing (142).

But Diderot's basic position is that the art of the actor is to impose the conscious intellect, in the form of aesthetic choices based on empirical knowledge from the observation of minute details, over the body. For Diderot, true talent was "knowing well the outward symptoms of the soul we borrow, of addressing ourselves to the sensations of those who hear us," and "of deceiving them by imitation of these symptoms" $(1957,53)$. For Stanislavski, the exact opposite is true, and his acknowledgement of the division of the self does nothing to change that. The key to an art of experiencing is not "technical virtuosity", but the creation of "not only the conscious but the unconscious aspect of the human mind" (quoted in Benedetti 2007, 118). The foundation of this is an underlying aesthetic view that nature is superior to mind in the act of creation. This in my view suggests that the search for a character's "real emotion" was never at the base of his System. As mentioned earlier, Pushkin's aphorism talks about the "truth of passions" and the "verisimilitude of feelings" in proposed (or, for Stanislavski, "given") circumstances. The expression of feelings has to "look right" rather than "be"; but the creative act of passion has to be true an actor must "react under the influence of passion, in character" (Stanislavski 2008, 43). This sounds very similar to what Shpet expressed in his 1921 essay. "An experience admits of many forms of expression, and an actor must possess the stage technique to give such inner experiences a variety of expressions". The authors' shared philosophical frame may be borne out in, for example, the idea that Stanislavski might have been receptive to the teachings of yoga in a metaphysical sense as early as 1906 (Tcherkasski 2012, 4). Note that for both Stanislavski and Shpet, an aesthetic sense of taste is necessary, but the material from which the actor makes these aesthetic choices is lived, inner experience. This is very different from either using emotional memory (which, according to Shpet, falls into psychologistic error and is not aesthetic) or from the Diderot model, where empirical observation is imposed by the mind in the form of physical expression. Diderot's method of imitating external form differs from the Method of Physical Actions that Stanislavski espoused later in his career, as the latter method was meant as a way of tapping into the inner creative state of lived experience, to which Diderot would have been completely indifferent.

As I stated earlier, acting schools in the English-speaking world have made efforts to adapt Stanislavski's methodologies for learning the art of acting. Graduates of acting schools should all be well-versed in the basic 
forms of the exercises described in An Actor's Work, or variations thereof. The paradox is that these same graduates will tend to practice (sometimes at a very refined level) an art of acting that can best be described using Stanislavski's language as an art of representation. It is worth remembering that this is, in Stanislavski's view, a respectable form of art, it is simply not the art that he advocates. It is rare in the English-speaking world, in my view, to see artists being encouraged to pursue what I think would be understood in Russia as an art of lived experience. What I am trying to note is that very often, in professional theatre in the English-speaking world, good theatrical performances tend to fall into what I think can be understood as art of representation, while in Russia a good performance will often fall into an art of lived experience. It's important to stress that I am not making a value statement about the acting done by actors in Russia against that done by actors in the Englishspeaking world: I have seen good and bad performances in both contexts. Craft, in the sense used by Stanislavski, can be and is often turned to by the adepts of either of these two main types of art.

Here, I have suggested that pedagogy focused on the methodological aspects of Stanislavski's system is often practiced in a vacuum, in the sense that the methodology may not lead to an art of lived experience; likewise, I have found that those who reject the methodological aspects of the System as it is understood in the English-speaking world can sometimes, in fact, come closer to an art of lived experience. For example, lost in the great "inside-out" vs. "outside-in" debate between Stanislavski and Meyerhold that students of acting have heard of so often is the fact that their views of what great theatre should fundamentally be were not so very different; both directors rejected naturalism and accepted realism (Meyerhold 1968: 270). Stanislavski, in turn, believed that the actor, in order to free up the spirit, must have a well-trained body, as his incorporation of Yoga techniques into the System underscores. What the two directors were debating, from the same metaphysical standpoint, was a question of methodology.

Where I think that we may find a key to Stanislavski's approach that proponents of different techniques and methodologies can use to move towards the art of lived experience is in his views on what he called the "creative state". I propose that is the same state that Shpet refers to when he writes that the presence of sympathetic expression, in the midst of the formal unity which is the style of a particular theatre production, is that which creates a "living" theatre (Shpet 82). Philosophically, we are closer to Rousseau and the German idealists than to Diderot. This interpretation would also, on the whole, seem true of the metaphysical positions expressed by $19^{\text {th }}$-Century Russian philosophy, but less so of the more empirical intellectual heritage of English and American philosophy. Given these practical consequences on the problem of translating the System for use in other languages, further research on the metaphysical foundations of Stanislavski's aesthetics may uncover new possibilities for artistic dialogue. Finally, more research on the relationship between Stanislavski, the greatest teacher of actors, and Shpet, a philosopher preoccupied with the art of the actor, is surely needed. 


\section{Works Cited}

Aristov, Vladimir. "G.G. Shpet i proekt sozdaniia im Akademii Moskovskogo khudozestvennogo teatra." Voprosy psikhologii 3 (2009): 108-15.

Benedetti, Jean. “A history of Stanislavski in translation.” New Theatre Quarterly 6, no. 23 (1990): 266-278.

. Stanislavski: an Introduction. New York: Routledge, 2004

. The Art of the Actor. New York: Routledge, 2007.

Cairns, Dorion. Guide for translating Husserl. M. Nijhoff, 1973.

Carnicke, Sharon Marie. "An Actor Prepares/Rabota aktera nad sobǒ̌, Chast' I": A Comparison of the English with the Russian Stanislavsky.” Theatre Journal (1984): 481-494.

. Stanislavski in Focus: An Acting Master for the Twenty-First Century. New

York: Routledge, 2009.

Dal', Vladimir. Tolkovyi slovar zhivogo velikorusskogo iazyka. $2^{\text {nd }}$ ed. 1880-1882. Moskva, Gos. izd-vo inostrannykh i natsionalnykh slovarei, 1955.

Diderot, Denis. "The Paradox of Acting" in Denis Diderot and William Archer. The Paradox of Acting; Masks or Faces? Two Classics of the Art of Acting. Introduction by Lee Strasberg. W.H. Pollock, trans. New York: Hill and Wang, 1957.

Dilthey, Wilhelm. Poetry and Experience. Rudolf A. Makkreel, and Frithjof Rodi, eds. Princeton, NJ: Princeton University Press, 1985.

Gadamer, Hans-Georg. Truth and Method. $2^{\text {nd }}$, rev. ed. London: Continuum, 2004

Gillett, John. "Experiencing or pretending - are we getting to the core of Stanislavski's approach?," Stanislavski Studies 1 (2012). Web. http://stanislavskistudies.org/category/issues/issue-1/

Hobgood, Burnet M. “Central Conceptions in Stanislavski's System.” Educational Theatre Journal 25, no. 2 (1973): 147-159. 
Hughes, R. I. G. "Tolstoy, Stanislavski, and the art of acting." The Journal of Aesthetics and Art Criticism 51, no. 1 (1993): 39-48.

Maxwell, Ian. "More than 'Dead Pet Acting': Legacies of Stanislavsky." Sydney Studies in English 30 (2008).

Meyerhold, Vsevolod. Stat'i, pis'ma, rechi, besedy, Ch. 2. Moscow: Iskusstvo, 1968.

Shpet, Gustav. “Theater as Art.” Russian Studies in Philosophy 28-3 (1989): 61-88.

Stanislavski, Konstantin. An actor prepares. Elizabeth Hapgood, trans. New York: Theatre Arts Books, 1936.

. Sobranie sochineniǔ: v deviàti tomakh. T. 6. Chast' 1: Statyi, Rechi. Otkliki. Zametki. Vospominanya: 1917 - 1938. I. N. Vinogradskaya, ed. Moskva: Iskusstvo, 1994.

Books, 1991. . My Life in Art. J.J. Robbins, trans. New York: Routledge/Theatre Arts . An Actor's Work: A Student's Diary. Jean Benedetti, trans. Routledge, 2008.

Stolovich, L.N. Krasota. Dobro. Istina. Ocherk istorii esteticheskoy aksiologii, Moscow: Respublika, 1994

Tcherkasski, Sergei. "Fundamentals of the Stanislavski System and Yoga Philosophy and Practice." Stanislavski Studies 1 (2012). Web. http://stanislavskistudies.org/category/issues/issue-1/

Tihanov, Galin, ed. Gustav Shpet's contribution to philosophy and cultural theory. Purdue University Press, 2009.

Tolstoy, Leo. What is Art? Maude Aylmer, trans. New York: Funk \& Wagnalls, 1904. 